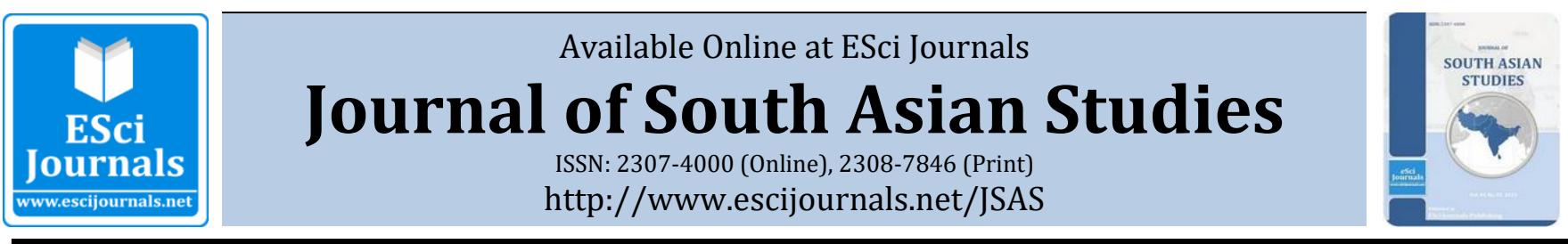

\title{
STATUS OF WOMAN IN ANCIENT INDIA: A COMPARATIVE STUDY OF NORTH INDIAN SOCIETY AND KASHMIR
}

\author{
aAsif R. Raina, bSheikh J. Ayub * \\ a Department of History, APS University Rewa, Madhya Pradesh India, Hadigam, Kulgam, Jammu and Kashmir, India. \\ b Department of Political Science, Degree College Kilam Kulgam, Kadder, Kulgam, Jammu and Kashmir, India.
}

\section{A B S T R A C T}

There is no doubt in saying that ancient Indian society was predominantly patriarchal in nature. The woman lived in an awful state and was lumped with shudras. The most inhuman practice was that of Sati which had gained social acceptance across the length and breadth of the society. But unlike the ancient Indian society, the society of Kashmir was almost free from all these elements which all time remained the core issues of Indian society. Sati system in India continued till British rule while as one finds just some literary references regarding sati in Kashmir. Even both the societies were religiously Hindu, both were ruled by Hindu dynasties and most importantly both were patriarchal in nature but both societies experienced different cultures. We argue that neither patriarchy nor religion can fully explain the subjugation of women. For instance, a woman in Kashmir enjoyed most of the social, political and economic rights than their counterparts in ancient India. Secondly, we argue that the caste system was not that rigid in Kashmir as it was in ancient India; hence caste mobilization was a usual affair in Kashmir and not in India. Thirdly, that the composite culture of Kashmir called Kashmiriyat has always been more inclusive, more accommodative than religious cultures. That is where a large difference is created between the two societies.

Keywords: Composite culture, Caste system, Dida, Kashmiriyat, Sati, Varna.

\section{INTRODUCTION}

Since the documentation of history writing started, the subcontinent has witnessed a style of history writing which did not take regions or other socio-political entities as different identities. This homogeneous type of approach was overwhelmed by a kind of ethnocentric mindset, hence gave least importance to understand the social and cultural differences across societies. Most of the scholars of Indian history have used and still use this peculiar approach, a centric one to reach the conclusions. The common usage of this centric approach has made it a dominant approach to history writing. The approach is applied to every corner of the country without taking into consideration geographical differences and internal potentials of different regions for transformation. This approach became the biggest obstacle in the way of documentation of regional or local history. Probably researchers on India's cultural past have focused on such

\footnotetext{
* Corresponding Author:

Email ID: sunatjavaidps@gmail.com

(C) 2018 ESci Journals Publishing. All rights reserved.
}

processes for pan India nationalism, hence hoodwinked many facts that could have proved otherwise handy in taking a different course to study the history. However, a favourable change is occurring with scholars setting for new methods for documenting regional history.

The paper uses historical and comparative methods to not only analyze the two ancient societies of north India and Kashmir but also to show that the difference in the social and cultural composition of these societies had made them different entities both historically as well as politically. It is argued that besides both the societies being patriarchal in nature, and both societies professing the Hindu religion, women were treated differently in both societies. In ancient India, the woman was no more than a lesser animal while as in the case of ancient Kashmir woman enjoyed a great amount of freedom than their counterparts in the rest of the subcontinent. It is hypothesized that the theory of patriarchy supported by a strict code of religion can explain woman subjugation in some case of north Indian society, however, it fails to explain the same for the society if ancient Kashmir. It is 
further stated that the accommodative and tolerant culture of Kashmiri society made it different than the rest of north India.

\section{HISTORICAL BACKGROUND}

The study of ancient North Indian society reveals that the position of woman was in an utter state of disturbance and highly deteriorated. The woman was one who could satisfy the needs of man and produce legitimate heirs. In the law book of Manu woman is described as a creature that was never independent. A virtuous wife is one who serves her husband as a god, even if he behaves badly, freely indulges his lust, and is devoid of any good qualities (Manu, 2000: 115). The society was so rigid that the birth of a female child was an unwelcome event. The daughter was considered as a source of misery while as a common notion was that only a son can be the saviour of the family (Altekar, 2016: 3). A gestation rite called Pumsavana was prescribed to ensure the birth of a male child and even Atharva Veda contains charms for changing a female fetus into a male one. The girl was generally considered liability and a burden on the family. In the whole ancient period, the woman enjoyed little liberty in Vedic age. During the Vedic period, if not fully, but woman enjoyed a fair amount of access to knowledge, could attend Sabah and various other social gatherings. Nationalist historians of twentieth-century often presented Vedic age as a golden age for a woman (Singh, 2013: 205). Altekar (2016) says that the position which woman occupied in Hindu society during Vedic age was much better. He further states that a woman played an important role in evolving a definite culture (Alteker, 2016: 1-26). There is no doubt in the fact that the Rig Veda mentions goddesses but none of them are as important as major gods. Woman as priests was non-acceptable and neither could woman participate in sacrifices on behalf of their husband; as far as the portion of hymns attributed to a woman in Rig Veda is minuscule. This suggests that the woman had limited access to sacred learning's.

Projecting Vedic society as golden age is generally regarded as reaction from nationalist historians of India to colonial rule. Such a reaction can be seen as a response to the oppression and humiliation of colonial rule (Singh, 2013: 191). This 'unashamed glorification' of the past, however, does not explain the paradigm shift that occurred in the Indian society when it changed from 'golden period' of the early Vedic period to a nearly 'dark ages' in the later Vedic period. Romila Thapar (2009) explains this glorification approach of nationalist historians as partly a reaction to James Mill's approach of Indian history and partly an effort in the building of national self-respect (Thapar, 2009: 10). The transition from low rigid Vedic society towards the highly rigid postVedic society even snatched the little fair amount of freedom from woman which they enjoyed before. The society no longer remained a society of equals and then onwards gender differences emerged as the main source of suppression of woman. There occurred perceptible changes in the status of woman after the Vedic age. Woman was debarred to sit in Sabah and participate in rituals. Later Vedic texts reflect the idea that the menstrual blood of women is dangerous and polluting. A menstruating wife wasn't supposed to participate in sacrifices. Tatriyaat Samihata reflects other taboos as well-it was inappropriate to talk, sit near, or eat food cooked by a menstruating woman (Singh, 2013: 205). The three varnas shared one common practice called Upanayana ceremony (beginning of education) and the recitation Gayatri mantra. Woman and shudra were deprived of both of these two and this led to the imposition of disabilities on shudras and woman that began towards the end of the Vedic period (Sharma, 1995: 122-25).

The members of higher varnas especially Brahmans flourished a culture of their making to dominate over the woman and the lower strata of the society. To maintain their position, they created several things that compelled the woman for willful obedience. The most noteworthy was to attempt to provide a theological base by propounding a 'Creation Theory' which postulated that the Brahman emerged from the head of Brama, and hence are the men of thinking, planning and decision making. Brahminical dominance was sustained by the politicoreligious philosophy that emerged in the later Vedic period and continued up to modern times (Manu, 2000: 6-7). The whole social and political order of the Indian society was based on two important concepts Dharma and Danda. Dharma is a Sanskrit term meaning something that holds the society together. It was defined as performance of duties according to one's own caste. To act according to the rules of his Dharma meant that a man must accept his position and role in society on the basis of the caste into which he was born and the norms which had been enunciated for that caste. On the other hand, Danda means force, coercion, discipline, and is generally used to mean coercive power of government. Dharma was used to establish the higher caste superiority especially 
that of Brahmans while as Danda was used to uphold Dharma by force. The rules of Dharma were framed by Brahmans themselves, hence, tried to maintain their superiority (Pantham \& Deutsch, 1986: 17). The society thus established on the caste hierarchies became static, and hence lacked any mobilization of caste or occupation. In order to check any social mobility, caste was linked with Karma. ${ }^{\text {i }}$ The society got divided into the "twiceborn" and the Shudras, the upper castes and the lower castes, unequal in their social, economic, legal and political aspects. The social hierarchies gave birth to economic and legal inequalities. Hindu scriptures codified laws and punishments according to various castes. There was no equality before the law. Rights were the privileges of the twice-born while as Shudras had only obligations. The burden of society fell heavily on the shoulders of these Shudars who could claim hardly any rights and privileges (Thapar, 2009: 28).

With their authority widening the Brahmans soon became the custodians of religion, morality and above all the code of conduct. The Brahmanical interpretations of religious texts placed them to a position where they easily began to enforce strict moral laws on woman. They preserved their authority by codifying the laws based on dharma and Karma. The impression one gets about the position of woman after Vedic age was that of progressive decline. To make her feel inferior, woman was bracketed with shudras. The shaapath Brahmna warns that reaching Pravrajya the teacher should not look at woman, the shudra, the dog, and blackbird because they are untruth (Sharma, 1995: 75). This is not the only text that makes mention about shudra and woman. The Parskar Grhysutra, Budhyana Dharmasutra and the law books of Manu, Chadrayana vow it not proper in any account to talk about woman, a shudra and an outcast. The woman and property were considered to be the main sources that disturbed the mind of a man. It was believed that woman and property were the roots of conflicts for the entire humanity. Woman was regarded as a sort of private property. She was considered incapable of exercising her independent will and could be given away or loaned as item of property (Sharma, 1995: 70). The Matryani Samhita refers 'men go to assembly, but no woman was entitled to go. Woman, as some instances suggest, were considered not more than gifts and commodities of exchange for instance in the reference for rajas gifting their daughters to win over sages (Singh, 2009: 205).

Regarding marriage, Dharmasutras suggest, girls should be married off as soon as they attain puberty. The marriage of girl was mainly decided by his father; and the opinion of mother and the daughter hardly mattered (Singh, 2009: 296). After marriage good woman was one who could behave like meek slave. These teachings are mentioned not only in Samritkars lawmakers but have also found place even in Buddhists texts. Woman enjoyed her right to life (though in a miserable state) only till her husband was alive. The evil practice of Sati did not recognize her life to be of any worth after the death of her husband. She was to end her life and burn herself alive on her husband's funeral. We have the references of sati from Mahabrta and the inscriptional not older than early sixth century AD (510) (Sharma, 1995: 97-98). The practice of sati came to an end when Raja Rammohan Roy urged William Bentinck to take necessary steps and declare the practice of sati illegal. It was fairly widespread in Bengal and Rajasthan when it was completely banned in 1829.

\section{POSITION OF WOMEN IN ANCIENT KASHMIR}

Unlike the north Indian society, the society of Kashmir was almost free from all these elements which all time remained the core issues of Indian society. Even both the societies were religiously Hindu, both were ruled by Hindu dynasties, but the composite culture of Kashmir kept the society intact and did not allow these social evils to make an easy entry into the Kashmiri society. The most significant feature of the society of Kashmir was that woman enjoyed a good amount of freedom in every sphere of life. The woman of Kashmir walked shoulder to shoulder with men, was it in learning or in the battlefield. There are references that woman participated in battlefields, the rise of Vijaymalla during the reign of king Harsha planned treason against the king. As the king's troops got ready Vijjayalla talking the horse bravely attacked the king's force and his wife kept holding his back on the horse (Rajataragini, VIII, Verses, 899-905). The woman in Kashmir was treated better than in their counterparts elsewhere in the world. They were sitting along with men in the court of Harsha, to which Brahspti described as the lovely ladies took place of Apsaras (Rajatarangini, VII, Verses. 945-949). The woman was not wholly and solely dependent on men rather could claim their rights too. Kalhana refers that after Harsha ascended the throne Sugala came before him to claim her position as chief queen (Ibid. Verses. 829-30). The striking feature of ancient Kashmir society was that woman had access to knowledge. Bilhana, the poet 
laureate at the court of Chaulkyas, while describing his homeland, stated that the woman of Kashmir spoke Sanskrit and Prakrit (the official and the upper caste languages) fluently (Bamzai, 1994: 205-06). In Kuttutmani Kayva, Damodargupta shows that women receive education in fields of sexual sciences, art of dancing, music, learn paintings, needlework etc.

In ancient India woman had certain property rights mostly limited to their jewellery, clothing etc. but had no such rights over immovable property and the assets. Their right to property included what was called by the smritkars as the stri-dhana (means woman's property these include jewelry clothes, household articles etc) (Singh, 2013: 299). Manu also mentions certain conditions in which women could be entitled to ancestral property ii but generally, the rule was that slaves and woman have no rights to the property. Unlike Indian woman, the woman of Kashmir enjoyed rights over property. There are references regarding Damra lady from Nilavasa held fief in her own right during the intrigue between king Jaysimha and his rival Bohja (Rajatarangini, VII, Verses. 3110-15). There are references of woman being donors e, g. queen Suryamti who made Brahmans rich by giving away cows, gold, horses, jewels and other presents to them (Rajatarangini, VII, Verses, 181-84). Kalhana makes further mention about the same queen who put an end to disgrace caused to the country by Padmraj, by handing over the savings of her own treasury (Rajatarangini, VII, Verse. 197). It is clear from these references that the woman owned immovable property and managed their estates.

\section{WOMAN AS RULERS}

In Kalhana's description of the history of Kashmir, we find three women rulers, Yashovati of Gonda dynasty, Sugandha of the Utpala dynasty and queen Dida. The queens either appeared as regent of their minors or they guided the kings in administrative works. The queens of Kashmir were as important as the king. The Kashmiri society did recognize the political role of the women and could easily accept her incapacity of a queen looking at all the affairs of the kingdom. The claim can be authenticated by referring to the event when pregnant queen Yashovati was installed on the throne by Brahmans (Rajatarangini, I, Verses. 70-73). Queens of Kashmir dominated the administration even as regents. King Gopalverman ruled under the guardianship of his mother Sugandha. After the death of Gopalverman, the queen herself assumed the royal power at the bidding of subjects and ruled for two years. Rajtarangni also mentions that the minor kings were guided by their mothers, for example, king Chakraverman first ruled under the guardianship of his mother Bopadti and then under his grandmother Ksillka for ten years (Rajatarangini, Book V, Verses. 228-290). When the throne felt vacant woman especially queens left no stone unturned to gain the power. Kalhana refers that after the death of king Hariraja the king's mother Srilekha who wished the throne for herself but did not succeed as the king's favorites and the king's milk brother Sagra made Ananta, her child son as king. Two Shahi Princesses iii acted as administrative advisors to King Ananta. After the death of the princess, the king came under influence of queen Suryamati who advised the king to handover throne to son Kalsa (Rajatarangini, VII, Verses. 134-179 and 229-233).

Queens have played a historical role in the ancient period of Kashmir. Mention is made of famous queen Dida who is regarded as the most popular figures of ancient Kashmir. Kashmir had witnessed the role of queen Dida who was phenomenally influential in political affairs and her husband Kshemagupta, could not escape from that influence hence earned the title of Didakshema ('Dida' first and 'Kshema' second) (Rajatarangini, VI, Verse. 177). She then became regent of her minor son Abhimanyu. Among lady rulers, Dida remained the most prominent figure who was well versed in politics. To gain power she even did not spear her grandson Bhimagupta whom she put to death and ascended the throne (Rajatarangini, VI, Verse. 188.). The noteworthy thing about queen was that even being lame; she became so prominent figure that Brahmans honoured their ladies with name Dida (Rajatarangini, VIII, Verses. 225-27.). It was not as if woman has a disability and was not fit for the rule. Hence woman emerged as prominent figures and was not taken for granted. Woman played the role of a regent for their minors, councilors of their husbands, and most importantly as rulers. The woman of ancient Kashmir also emerged as donors of wealth, temple makers and even built towns. The queen Sugandah built the town of Gopalpoura. She also built Gopalmath, Gopalkeshva, the two famous temples (Rajatarangini, V, Verse. 244). During the reign of Queen Dida, we see a long list of constructions including temples of Abhimanysavmi, Didasavami etc (Rajatarangini, VI, Verses. 299-306). Mention is also made of other queens as well who became famous for their construction works. Queen 
Surayamati, Queen Angalekha and queens of king Meghavan fall in this category (Rajatarangini, VII, Verse. 282. VIII, Verse. 448).

\section{MARRIAGE AND THE PRACTICE OF SATI}

The society of Kashmir preferred social values over religious. The social values, liberal in their nature, were providing woman a good space to exert herself in almost all fields. This liberal tendency of the society and its accommodative nature made society free from most of the social evils that could curb the freedom of woman. There were no restrictions on inter-caste marriage. For instance, we have references regarding inter-caste marriages when the Gargachandra'iv wife Chuda brought two daughters in marriage to king Susala (Rajatarangini, VIII, Verses. 459-60). The other interesting reference regarding the liberal approach towards marriage is when the king Chakarverman married with two Domb (low caste) girls and gave them the position of chief queens (Rajatarangini, V, Verse. 387). The references cited to make the fact clear that there were no restrictions on inter-caste marriage. Regarding the proper age of marriage, there is no evidence forthcoming from Rajtrangni. But it seems pre puberty marriages were not in vogue. The polygamy was much prevalent than polyandry. There were however, no restrictions on widow remarriages, for example, king Pratapadatiya II married the wife of a rich merchant Nona (Bamzai, 1994, p. 208). The remarriage of Kota Rani with Udayaandya after the death of her husband king Rinchana can be cited as another example. This showed there were no restrictions on widow remarriages.

\section{SATI}

The practice of sati has hardly found ground in the ancient Kashmir. Though there are certain references regarding sati in Rajtrangi, sati was no common practice. Further, there are no archaeological findings that can hint about the practice of sati in ancient Kashmir. It seems that there might have been certain individual cases of sati without it being accepted as a popular custom like in India. Kalhana praises Damara lady who practiced sati. In his words 'we have neither seen nor heard of another such deed was done' (Rajatarangini, VIII, Verse. 2334). After the death of king Yasakra among ladies of seraglio, only Trillokyadevi practiced sati while as the other queens did not follow (Rajatarangini, VII, Verse. 107). This indicates that practice of sati had not acquired much importance and was not a popular phenomenon. But Kalhana has praised the ladies who had performed sati because he himself was a Brahman. Kalhana also makes a mention of the sati performed by queen suryamati after the death of her husband and wives of king Uccala (ibid). Sati remained more or less an individual practice rather than a popular culture like in Kashmir.

\section{CONCLUSION}

Although the ancient Indian society and the society of ancient Kashmir had many of the great similarities they also differed on many accounts. Both the societies, despite experiencing patriarchy had all together received different impacts. We find a very rigid, static society in ancient India where woman got reduced to the level of a lesser animal; she was debarred of enjoining many of the rights which were enjoyed by their counterparts in Kashmir. It is surprising to see both societies professing Hindu religion, but the religion could not cultivate the same kind of culture in both societies. If religion became a dominating force for Brahmans in India, it could not bring them the same socio-political status in case of Kashmir. It is quality of accommodation, tolerance and pluralism that made Kashmir look completely a different society in comparison to the rest. In ancient Indian society we come across the works of Katuliya, Manu, yajnavakiya, who not only dwelled with the art of statecraft but also left no stone unturned in justifying and providing legitimacy to Brahaminical dominance. These writers codified laws and interpreted texts to maintain status quo. These texts made woman and the lower strata of the population vulnerable. But such kind of texts and literature found no place in Kashmir. There is no doubt in the fact that the Brahmans found themselves at the top in both the societies, but their positions differed to a great extent. The point can be illustrated by saying that while in India the Brahmans were the sole law givers, law interpreters and none could go against their will but in case of Kashmir Brahmans were so weak in position that they sometimes had to go for hunger strikes to make their demands felt.

\section{REFERENCES}

Altekar, A. S. (2016). The Position of Woman in Hindu Civilization. New Delhi: Motilal Banarsidass.

Bamzai, P. (1994). Cultural and Political History of Kashmir. New Delhi: ML Publications.

Ghurye, G. S. (1961). Caste and Race in India. Bombay: Popular Prakashan.

Pantham, T., \& Deutsch, K. L., (eds.). (1986). Political Thought in Modern India. New Delhi: Sage Publications. 
Sharma, R. S. (1995). Perspectives in Social and Economic History of Early India. New Delhi: Munshiram Manoharlal.

Singh, U. (2013). A History of Ancient and Medieval India. New Delhi: Pearson.

Singh, U. (2009). Ancient Indian Social History, Some Interpretations. . New Delhi: Orient BlackSwan.
Smith, W. D. (2000). The Laws of Manu. Haryana: Penguin Books.

Stein, M. A. (2007). Kalhana's Rajatarangini Vol. 1. Srinagar: Gulshan Books.

Stein, M. A. (2007). Kalhana's Rajatarangini Vol. 2.Ssrinagar: Gulshan Books.

i In Hindu mythology an individual's birth into a particular caste is not accidental but a result of his Karma or actions in his previous life. Dharma and Karma are integrally connected. An individual's Karma determines his caste, and therefore his Dharma, and his Dharma defines his rightful Karma.

ii If a female is made an appointed daughter, she is entitled to property. Similarly, Manu states that when property is divided among brothers, the brothers should individually give their virgin sisters from their own portions, a quarter share of each one's own portion Manu, Verse, 119.

iii These princesses came to Kashmir as refuges and became political advisors to King Ananta. Their names were Rudrapala, Diddapala. See footnote to Verse 144 of Rajtarangni, Book VII.

iv Gargachandra belonged to Damara class, the lower castes. 